\title{
Application of Meticulous Management in Logistics Management in Colleges and Universities
}

\author{
Wang Tie \\ Qiqihar Medical School, Qigihar, Heilongjiang, 161006
}

Keywords: meticulous management; logistics management; colleges and universities

\begin{abstract}
In recent years, with the development of the economy and the progress of the times, the education of our country has been greatly developed and the reform of education is constantly advancing and perfecting. The main content of the educational reform is to change the traditional mode of education, but at the same time, the reform of the management of colleges and universities is also made, and the concept of fine management is put forward to teach colleges and universities. The education reform has taken a new step. This paper discusses the application of fine management in the logistics management of colleges and universities, which aims to promote the continuous improvement of the management of colleges and universities, and offer suggestions for the reform of education in our country.
\end{abstract}

Since the reform and opening-up, the socialist modernization of our country has made a gratifying achievement. The progress of the field of education has attracted more world attention, and respect for talents and knowledge have become the mainstream of our country's development. In recent years, with the progress of theoretical research and the accumulation of practical experience, the concept of fine management has been put forward. Fine management focuses on the "essence" of management, refining management details and improving management quality to become the target of fine management. In the logistics management of colleges and universities, because of its own particularity, the fine management should be able to improve the management quality better, mobilize the enthusiasm of the staff, and thus realize the purpose of fine management.

\section{The Intension of Fine Management}

The concept of fine management was originally proposed by the Japanese, mainly aimed at the details of management, aimed at improving the efficiency and quality of management and improving the satisfaction of the customers. In practice, it is a concept of traditional extensive management. Fine management focuses on management details. The purpose is to create a perfect management model, reduce management costs, improve management efficiency, and have clear power and responsibility, so that everyone can clear their own management goals and improve individual management ability. To achieve a win-win situation in the end. The purpose of meticulous management is to improve the quality of management and reduce the cost of management. For the fine management of logistics in Colleges and universities, we should first set up a sound management standard. After that, we should resolutely implement it in accordance with the standard of management, make the work fine, fall to the details, and determine the success or failure in detail. Only by doing the work fine, can the logistics work be guaranteed. The importance of logistics in Colleges and universities is self-evident. It is the security work and life guarantee of the whole school and students. The perfect logistics management can provide a comfortable environment for the teachers and students in Colleges and universities, and the fine management is an important way to improve the logistics management of colleges and universities. 


\section{The Significance of Meticulous Management Applied to Logistics Management in Colleges and Universities.}

According to the current system of our country, colleges and universities belong to institutions, the staff of colleges and universities are mainly staffing personnel, and the Logistics Department of colleges and universities is one of the management departments of colleges and universities. The staff of colleges and universities naturally belong to the personnel of national cause, and some managers have the idea of "iron rice bowl" because of this thought. It leads to the inactive management and backward management concept, which results in the confusion of logistics management in Colleges and universities. And meticulous management, according to modern management mode, renewing management concept, can enhance the consciousness of personnel crisis, let the manager realize the competitive state of the competent person and the mediocre. This requires the managers to learn constantly and improve their own management ability, so as to ensure that they are not eliminated and serve the teachers and students more carefully. Meticulous management can improve the enthusiasm of logistics managers and update management concepts.

There are many problems in the traditional management mode of the Logistics Department of colleges and universities, such as unclear power and responsibility, confusion of division of labor, and lack of post and leakage. And the fine management can be put forward by setting up a standard workflow and system to restrict all the staff. Once the problem occurs, it can be directly responsible to people, avoid the mutual prevarication of responsibility, make the work more clear and ensure the effective management, in addition, by changing the traditional management model of extensive type. It also can reduce management costs, improve work efficiency and promote continuous improvement of management.

As far as the current personnel of the Logistics Department of colleges and universities are concerned, whether it is the management staff of the logistics department or the front-line staff, there is a large gap in the educational background and ability, some employees can not match the ability, and the overall quality of the department needs to be improved. And fine management can allow all employees to participate in the management, which is not only conducive to the improvement of the quality of personnel, but also to promote the continuous learning of personnel, improve management level, and establish a sense of ownership, in addition, fine management is also conducive to the creation of a good learning atmosphere, more in line with the academic academic academic. The atmosphere improves the learning ability of the logistics department, and opens up a new channel for the improvement and promotion of personnel.

\section{Problems Existing in Logistics Management in Colleges And Universities at Present}

At present, most of the colleges and universities in our country belong to the state institutions, and the Logistics Department of colleges and universities usually implements the supply system. All the expenses in the latter Department depend on the state and the local financial supply. Based on this model, the logistics staff are lazy and the service consciousness is weak.

The logistics department is a service department in the whole school management system, which serves the teachers and students in the whole school. In fact, the actual situation is on the contrary. Because of the supply system of the whole school, the staff of the logistics department are lack of active power and can not take the active service for the school and students, and the logistics department should be needed once the problems occur. Maintenance and supply, often a wide range of procedures, long delay can not be implemented, in the end, once the problem, the responsibility of mutual prevarication, should have served the Department as the "officer", let the whole school teachers and students, so it is imperative to improve the service consciousness of the logistics personnel.

The unused problem of the personnel is a prominent problem at present. One of the important responsibilities of the logistics service department is to maintain and replace the things in the school. From the present actual situation, although there are many things in the school, the problem of 
maintenance and replacement is a few, and most of the maintenance personnel are idle. The waste of human resources can not be endless. On the one hand, it causes unnecessary expenses to the school. On the other hand, the logistics management has caused confusion. The excessive idle personnel will have unnecessary trouble. In recent years, the staffing of the rear service department of the school has an increasing trend. This problem will be more serious.

\section{The Application of Meticulous Management in Logistics Management in Colleges and Universities}

As one of the service departments of colleges and universities, the logistics department is responsible for the service of teachers and students in Colleges and universities. Therefore, the logistics personnel need to make clear departmental responsibilities and departmental status. Both the logistics managers and the front-line staff should clearly define their own job responsibilities, improve their awareness, and strengthen the establishment of the service consciousness. The teachers and students provide a practical service guarantee mechanism.

First of all, we should correctly interpret the concept of meticulous management and improve service awareness. The essence of fine management lies in the management of details. It is necessary to start from the details, realize the meticulous service, strengthen the daily inspection and maintenance, and improve the management efficiency.

Secondly, fine management requires scientific standards and management measures, and perfect management comes from scientific standards and systems. Therefore, in order to improve the service management system in the Logistics Department of colleges and universities, we should first formulate scientific management standards, clear power and responsibility, and realize meticulous and continuous solutions to services and questions. Improve the quality of service.

The foundation of fine management is the perfect management system, so in order to carry on the fine management, the first step is to establish a perfect management system, so that there are laws and regulations, the law must be carried out, the logistics work is carried out orderly, the logistics service work is guaranteed, and the actual work content should be practicable.

Secondly, in accordance with the requirements of fine management, we must constantly innovate management means, whether it is for the management of personnel within the department or the management of the school as a whole, we must constantly innovate management means, improve the enthusiasm of the staff, establish a scientific and fair assessment system, carry out the management mode under the mediocre of the competent people, and serve the service. Those who are not very active and work hard must deal with it promptly, exchange jobs and talk with others, and ensure the orderly management of logistics.

The idleness of logistics personnel is one of the bottlenecks of logistics management in Colleges and universities. To solve this problem, it is necessary to improve the work saturation and enrich the work content according to the requirements of fine management. For some maintenance personnel and timely service maintenance personnel, in the absence of normal work tasks, to strengthen the routine work of combing and inspection, prevention in the bud, the service will be fine out, the real implementation of logistics services, improve the satisfaction of teachers and students. In addition, we can also increase the content of study, strengthen the study of logistics knowledge, enrich the work and life of the staff, constantly mobilize the enthusiasm of the logistics personnel, improve the work efficiency and optimize the allocation of human resources.

Fine management also requires leaders to constantly improve their understanding of management, accept new management methods, and promote the continuous realization of new management mode. At present, in the logistics management of colleges and universities in China, one of the important reasons that the implementation of fine management is not in place is that the leaders do not attach importance to it. The leaders of the Department are more keen on the traditional management mode, and they are not willing to accept the new management mode and refuse to try new management methods. This leads to the fine management of this scientific management way can not be true. As a result, in the logistics management of colleges and universities, leaders should first pay attention to management, constantly improve their understanding level, accept new things, 
continuously in their own management, use fine management, improve the efficiency of department management, and thus promote the quality of management of the Logistics Department of colleges and universities to promote the quality of management.

As far as the Logistics Department of China's colleges and universities is concerned, the comprehensive quality of its staff is insufficient. Some logistical staff only rely on professional technology in the work, not willing to accept new things, learning ability is poor, can not actively study, and can not take the initiative to study business, in this case, fine. It is necessary to improve the learning ability of the logistics staff and improve the comprehensive quality of the staff. As the management personnel of the logistics department, they can organize regular internal training and irregular external learning. The internal training is taught by the department leaders or the school principals to carry out the logistics business, so as to improve the staff. Business level, irregular external training can organize personnel to other outstanding universities to visit, study other colleges and universities logistics management methods, observe the state of logistics work in other colleges and universities, to improve the quality of management, promote the purpose of staff learning, thus comprehensively improve the level of logistics management in Colleges and universities, help to improve the level of logistics management in a comprehensive way. The development of the school of force.

In addition to the need for a perfect system, fine management needs a good management atmosphere, and a good management atmosphere is based on high management level of leadership and high executive staff. Fine management is not only applicable to enterprise management, but also extremely fit in the logistics management of colleges and universities. On the one hand, the fine management of university logistics can continuously improve the quality of the logistics management in Colleges and universities, and promote the development of university service. On the other hand, it can constantly improve the level of the management of the University, enhance the learning ability, improve the quality of the management of the University, and promote the development of the colleges and universities, so as to promote the reform of the universities in China. The fine management is a new management mode, which is a new management method to conform to the trend of the times. As long as it is applied scientifically and rationally to the management of colleges and universities, it will provide a powerful theoretical guarantee for the development of universities in our country.

\section{Concluding remarks}

With the deepening of our country's reform, all aspects of our society are developing actively, complying with the trend of the times, exploring the way and direction which are beneficial to the development of our country. The continuous development makes us realize that the development of education is the fundamental. Therefore, the reform of our country is unprecedented, no matter what the reform is in the field of education. The educational reform in the stage is in full swing. As the position of training the talents in our country, the university is the key area of the education reform, and the reform of the university education is not only the reform of the teaching, but also the reform of the management system. The perfect management system will naturally promote the reform of the whole university and realize the reform. The purpose of leather. This article only analyzes and discusses the reform of logistics management in Colleges and universities. The existing problems are the inevitability of the historical development stage. It is believed that in the future development, the logistics management of colleges and universities in our country must be constantly rising, providing strong support for the education reform of our colleges and Universities. At the same time, it also helps the reform process of our country as a whole. It is a powerful guarantee for our country to achieve a well-off society in an all-round way.

\section{Acknowledgement}

Foundation project: Heilongjiang Provincial Education Department Project: university logistics service education based on caring theory (2016-KYYWF-0903). 


\section{References}

[1] Sheng-Ai L I, Chen M X. On the Application of Meticulous Management to Talent Cultivation of English Majors in Agricultural University[J]. 2016(icss).

[2] Xie S N, Office S A, University L. The Analysis of Meticulous Management in Financial Assistance of University Students[J]. Journal of Shenyang Institute of Engineering, 2016.

[3] Yang G, Department N. Application Effect of Meticulous Management in Nursing Management of Neurology Department[J]. China Health Standard Management, 2017.

[4] Xue-Dong X U, Fan W Y, Xin-Xia W U, et al. Exploration of Methods of Meticulous Management of Operation Room in Tertiary Hospitals[J]. Hospital Management Forum, 2017.

[5] Yumei L V. Application Analysis of Meticulous Management in Clinical Nursing Interns Teaching[J]. China Continuing Medical Education, 2017.

[6] Liu D, An Z, Jiang Q. Construction of Practice System for the Logistics Management Specialty in Application-oriented Universities_—Based on the Practice of Constructing Specialty Clusters[J]. Journal of Heihe University, 2017.

Introduction: Wang Tie (1982--) male, Qigihar city man, master, Qiqihar Medical School associate researcher, main research direction: logistics management, ideological and political education. 